\title{
Characterization and Pathogenicity of Thanatephorus cucumeris from Sugar Beet in Minnesota
}

Carol E. Windels, Associate Professor, and Rita A. Kuznia, Research Fellow, Northwest Experiment Station, University of Minnesota, Crookston 56716, and Jack Call, Agriculturist, American Crystal Sugar Company, East Grand Forks, MN 56721

\begin{abstract}
Windels, C. E., Kuznia, R. A., and Call, J. 1997. Characterization and pathogenicity of Thanatephorus cucumeris from sugar beet in Minnesota. Plant Dis. 81:245-249.

In 1993, hymenia of Thanatephorus cucumeris occurred on petioles of sugar beet leaves, but disease was not observed on leaves, crowns, or roots. Of 33 cultures isolated from sugar beet, 28 were identified as Rhizoctonia solani AG-3 (from four fields planted to potatoes in 1992) and five isolates were AG-5 (from one field planted to wheat in 1992). These isolates of $R$. solani AG-3 and AG-5 were nonpathogenic to moderately pathogenic on sugar beet seedlings (stands ranged from 49 to $95 \%$ ). The same isolates were nonpathogenic when inoculated on 8-week-old sugar beet roots (root rot indices were $\leq 1$ [0 to 7 scale]). All isolates of $R$. solani AG-3 (but none of AG-5) formed sclerotia on roots. Disease indices (0 to 4 scale) on potato sprouts at $10^{\circ} \mathrm{C}$ were low, did not differ significantly $(P=0.05)$ among isolates and the control in either of two experiments, and averaged 0.9 for 14 isolates of AG-3, 0.5 for three isolates of AG-5, and 0.5 in the control. All isolates of AG-3 (but none of AG-5) formed sclerotia on potato seed pieces. When potato sprouts were grown at $25^{\circ} \mathrm{C}$, disease indices were low (averaged 0.4 in each of two experiments), but four isolates of AG-3 and three of AG-5 had disease indices significantly $(P=0.05)$ higher than those of the uninoculated control. Sclerotia were not observed. The presence of hymenia of T. cucumeris is significant in that sexual reproduction and inoculum production occurred on a nonhost crop and were related to AGs of $R$. solani associated with the previous crop (AG-3 for potato and AG-5 for wheat).
\end{abstract}

Additional keywords: Beta vulgaris, Solanum tuberosum

Thanatephorus cucumeris (A.B. Frank) Donk is the teleomorph of Rhizoctonia solani Kühn. In 1947, Kotila first reported the occurrence of hymenia of T. cucumeris on sugar beet (Beta vulgaris L.) on the underside of leaves adjacent to foliage blight lesions (13). In this work, which predated the anastomosis group concept (22), Kotila attributed foliage blight to strains of $R$. solani that differed from those causing Rhizoctonia root and crown rot or dry rot canker of sugar beet. Anastomosis grouping (AG) among isolates of $R$. solani has subsequently enabled identification of the cause of Rhizoctonia root and crown rot as AG-2-2 $(19,22)$, but the

Corresponding author: C. E. Windels

E-mail: cwindels@mail.crk.umn.edu

Current address of R. A. Kuznia: Northrup King Co., 317 330th St., Stanton, MN 55018.

Contribution No. 22,374 of the Minnesota Agricultural Experiment Station.

Accepted for publication 17 December 1996.

Publication no. D-1997-0121-05R

(C) 1997 The American Phytopathological Society group that Kotila observed remains unknown.

In 1978, a report from Japan contained a description of a foliar blight of sugar beet caused by $R$. solani AG-2-2 of T. сисиmeris (16). Hymenia of T. cucumeris first appeared on petioles, followed by a foliar blight, presumably after basidiospore discharge $(15,17)$. Herr (9) reported hymenia of $T$. cucumeris on sugar beet in Ohio in 1979 and 1980. Hymenia first were observed on diseased petioles of plants with Rhizoctonia root and crown rot, and 10 to 14 days later, a leaf blade blight developed. Most isolates were $R$. solani AG-2, but AG-4 and binucleate Rhizoctonia-like fungi also were identified (9). Olaya and Abawi reported hymenia of $T$. cucumeris on table beet in New York, and most isolates were $R$. solani AG-2-2 (21).

On sugar beet grown in the Red River Valley of Minnesota and North Dakota and in western Minnesota, $R$. solani AG-1, -2$2,-4$, and -5 cause damping-off, and AG-22 causes root and crown rot (28). Other broadleaf crops rotated with sugar beet, such as dry bean, soybean (18), flax, and potato (2), are susceptible to $R$. solani, with the presence of an AG being influenced by the cultivated crop $(8,20)$.
On 9 July 1993, sugar beet plants bearing basidiospores of $T$. cucumeris were observed in a field near East Grand Forks, Minnesota. The hymenial layer occurred on petioles near the sugar beet crown and appeared as a superficial dusty growth that was white to gray in color (Fig. 1). Disease symptoms were not observed on foliage, crowns, or roots of these plants.

The objectives of our study were to identify isolates of $R$. solani from hymenia of $T$. cucumeris on sugar beet plants to anastomosis group and to determine optimal growth temperature and pathogenicity of these isolates on sugar beet and potato (Solanum tuberosum L.). A brief report has been published (27).

\section{MATERIALS AND METHODS}

Collection and isolation. Sugar beet plants bearing hymenia of $T$. cucumeris were collected ( 3 to 10 per field) from one field in early July and from three in early September 1993 that were located near East Grand Forks. Plants also were collected in late July from a field near Crookston, Minnesota. Sections of petioles bearing hymenia (1 to $2 \mathrm{~cm}$ in length) were placed on Difco potato-dextrose agar (PDA). After 5 to 7 days, cultures were transferred to water agar (WA), and within 24 to $48 \mathrm{~h}$, they were hyphal-tipped and transferred to PDA. The 33 cultures were microscopically examined 5 to 7 days later and confirmed as having hyphal characteristics typical of $R$. solani (26).

Characterization of isolates. Anastomosis tests consisted of pairing the cultures with known AG test cultures provided by Neil A. Anderson, Department of Plant Pathology, University of Minnesota, St. Paul. Pairings were made on microscope slides coated with $2 \%$ WA, incubated at 20 to $22^{\circ} \mathrm{C}$ for 24 to $48 \mathrm{~h}$ or until hyphae started to overlap and intermingle, stained with lacto phenol-cotton blue, and microscopically examined for hyphal anastomosis $(22,26)$. At least two slides were examined to verify each identification. Cultures were stored at $-80^{\circ} \mathrm{C}$ on sterile barley grains (14).

Temperature for optimal growth. Growth rates of cultures of $R$. solani from $T$. cucumeris hymenia on beets were determined so that pathogenicity tests could 
be done at temperatures most favorable for growth. A 9-mm-diameter disk from the margin of a 5-day-old culture on PDA was placed near an inside edge of a petri dish containing $20 \mathrm{ml}$ of PDA. Dishes were placed in plastic boxes $(40 \times 27 \times 17 \mathrm{~cm})$ and incubated at $5,10,15,20,25$, and $30^{\circ} \mathrm{C}$. After $24 \mathrm{~h}$ (to allow agar and fungus to equilibrate to incubator temperatures), a baseline was drawn on the bottom of a petri dish at the colony margin. Hyphal growth was measured from the baseline to the colony margin after $72 \mathrm{~h}$. Controls included tester isolates of $R$. solani AG-3 and -5 . The experiment was arranged in a split-plot design of four replicates with temperature as the main effect and was repeated.

Pathogenicity on sugar beet. Pathogenicity of 32 cultures of $R$. solani (plus tester isolates of AG-3 and -5) was evaluated on sugar beet seedlings by an inoculum-layer technique $(10,25)$. Soil mix consisted of field soil, sand, and peat moss $(3: 1: 1, \mathrm{vol} / \mathrm{vol} / \mathrm{vol})$ that was moistened and autoclaved for $1 \mathrm{~h}$ on each of two consecutive days. Bottoms of plastic pots $(10 \mathrm{~cm}$ diameter) were lined with paper toweling, and $250 \mathrm{~cm}^{3}$ of soil was added and gently packed. A 7-day-old culture on 2\% WA (9 $\mathrm{cm}$ diameter) was placed on the soil surface and cut into quarter sections to allow passage of water and then covered with 50 $\mathrm{cm}^{3}$ of soil. Twenty-five sugar beet seeds of Maribo Ultramono that had been dipped in $70 \%$ ethanol, placed in $1 \% \mathrm{NaOCl}$ for 2 to $3 \mathrm{~min}$, rinsed twice in sterile distilled water, and dried under a hood were placed equidistantly on the soil surface. Then, 50 $\mathrm{cm}^{3}$ of soil was placed over the seed and gently packed. Controls included WA added to soil and soil without WA. Pots were placed in incubators at $25^{\circ} \mathrm{C}$ in a randomized complete block design of six replicates and watered to keep soil moist. Stand counts were made 3 weeks after planting. The experiment was repeated.

To fulfill Koch's postulates, dying seedlings (three per pot) were collected, rinsed in tap water, surface-treated with $0.5 \%$ $\mathrm{NaOCl}$, rinsed twice in sterile distilled water, and placed on PDA acidified with $50 \%$ lactic acid, five drops per $100 \mathrm{ml}$ of agar (APDA). Cultures were hyphal-tipped and identified to AG as previously described.

Pathogenicity of $R$. solani (same cultures as for seedling tests) also was evaluated on older sugar beet roots. Inoculum was grown on kernels of dent corn that were soaked in distilled water for $12 \mathrm{~h}$, drained, and autoclaved at $121^{\circ} \mathrm{C}$ for 60 min on two consecutive days. Two $1.5-\mathrm{cm}-$ diameter disks from the margin of a 5-dayold colony of $R$. solani on PDA were placed in a jar $(475 \mathrm{ml})$ containing about 200 kernels. For the control, two disks of PDA were placed in jars containing kernels. Inoculum was incubated at $23 \pm 2{ }^{\circ} \mathrm{C}$ for 14 days and shaken every 2 days.
Bottoms of 15-cm-diameter plastic pots were lined with paper toweling, and 850 $\mathrm{cm}^{3}$ of autoclaved soil mix (prepared as for the seedling test) was added and gently packed. Four sugar beet seeds (surfacetreated as previously described) were placed in the center of each pot, covered with $250 \mathrm{~cm}^{3}$ of soil, and watered. About 2 weeks after planting, all but the most vigorous seedling were removed from each pot. Sugar beet roots were inoculated 8 weeks after planting. Soil was scraped away from the root to a soil depth of $2 \mathrm{~cm}$, and two Rhizoctonia-colonized corn kernels were placed against the root surface. Two autoclaved corn kernels were placed on roots of control plants. Soil was pushed back to the root surface, and an additional $250 \mathrm{~cm}^{3}$ of soil was added to cover the crown, a practice that favors disease development (23). Pots were arranged in the greenhouse in a randomized complete block design of six replicates. The greenhouse was at $25 \pm 2{ }^{\circ} \mathrm{C}$ with radiation of $400 \mu \mathrm{E} \cdot \mathrm{s}^{-1} \cdot \mathrm{m}^{2}$ for $16 \mathrm{~h}$ daily. Roots were rated 3 weeks later on a 0 to 7 scale (6) where $0=$ healthy and $7=100 \%$ rotted. The experiment was repeated.

Reisolation of $R$. solani was done for each treatment (one to two roots per isolate) by excising a cube of tissue (about $1 \times$ $1 \times 0.2 \mathrm{~cm}$ ) from the edge of the lesion. Isolations were made, and AGs were identified, as previously described.

Pathogenicity on potato. Tests were conducted following a procedure modified from Carling and Leiner (4). Certified potatoes of cultivar Norland that had broken dormancy and were free from sclerotia were surface-treated by dipping them in $95 \%$ ethanol and then soaking them in $1 \%$ $\mathrm{NaOCl}$ for $5 \mathrm{~min}$. Then tubers were rinsed twice in sterile distilled water, air-dried, and cut into single-eye seed pieces (40 to $60 \mathrm{~g}$ each) immediately before planting. Bottoms of plastic square pots $(11.4 \times 11.4$ $\times 11.4 \mathrm{~cm}$ ) were lined with paper toweling, and $150 \mathrm{~cm}^{3}$ of autoclaved soil (prepared as previously described) was added. A seed piece was placed on the soil surface and covered with $50 \mathrm{~cm}^{3}$ of soil. Then, 12 disks (7 mm diameter) from the margin of a 2- to 3-day-old culture of $R$. solani on PDA were placed on soil about $1 \mathrm{~cm}$ above the seed piece and covered with $250 \mathrm{~cm}^{3}$ of soil. A limited number of seed pieces free from sclerotia of $R$. solani were available, so three to four isolates from each of the five fields were selected for pathogenicity tests (total of 17 isolates). Half of the pots for each treatment were placed in a dark incubator at $10^{\circ} \mathrm{C}$ because previous reports $(4,5)$ indicated that AG-3 was more pathogenic to potato sprouts at $10^{\circ} \mathrm{C}$ than at higher temperatures. The remainder were placed in an incubator ( $16 \mathrm{~h}$ day) at $25^{\circ} \mathrm{C}$, which favors disease caused by $R$. solani AG-5 (3) and optimal growth of cultures. Controls (for the 10 and $25^{\circ} \mathrm{C}$ experiments) included tubers treated with disks of WA.
Pots were watered when the soil surface became dry. For each temperature, pots were arranged in a randomized complete block design of five replicates. The experiment was repeated.

Potato sprouts were evaluated for disease at 6 weeks after inoculation at $10^{\circ} \mathrm{C}$ (4) and 2 weeks after inoculation at $25^{\circ} \mathrm{C}$ (3). A 0 to 4 scale was used (4) where $0=$ no lesions; $1=$ minor damage, one to several lesions $<5 \mathrm{~mm}$ long; 2 = moderate damage, lesions $\geq 5 \mathrm{~mm}$ long and girdling some sprouts; $3=$ major damage, large lesions and girdling and death of most sprouts; and $4=$ all sprouts killed.

Reisolation of $R$. solani was done for all sprouts or seed pieces where either the fungus or symptoms of disease were observed. A cube of tissue (about $1 \times 1 \times 0.2$ $\mathrm{cm}$ ) was excised and prepared, and the AG was identified, as previously described.

Data analysis. Analyses of variance were computed with SAS statistical analysis software (SAS Institute, Cary, NC). When needed, transformations were used to stabilize variances. Treatment means were compared with Fisher's protected least significant difference (LSD), $P=$ 0.05 .

\section{RESULTS}

Identification. The 28 cultures isolated from petioles of sugar beet plants bearing hymenia of $T$. cucumeris in four fields near East Grand Forks were identified as $R$. solani AG-3. These fields had been planted to potatoes the previous season; overwintered potato culls and pieces were observed on the surface of the soil in areas where hymenia of $T$. cucumeris were observed. The five cultures collected near Crookston were identified as $R$. solani AG-5; the field had been planted to spring wheat the previous season and had no history of potato production.

Temperature. Isolates of $R$. solani AG5 grew faster than isolates of AG-3 at 20, 25 , and $30^{\circ} \mathrm{C}$ but were similar at 5,10 , and $15^{\circ} \mathrm{C}$ in both experiments (data not shown). In the first experiment, all isolates of $R$. solani AG-5 and AG-3 (except one) grew most rapidly at $25^{\circ} \mathrm{C}$ (one isolate of AG-3 grew most rapidly at $20^{\circ} \mathrm{C}$, data not shown). When the experiment was repeated, 15 isolates of $R$. solani AG-3 grew most rapidly at $25^{\circ} \mathrm{C}$ (including the tester), while the other 12 isolates of AG-3 grew best at $20^{\circ} \mathrm{C}$. All isolates of AG-5 grew optimally at $25^{\circ} \mathrm{C}$; the tester isolate of AG5 grew equally well at 20 to $25^{\circ} \mathrm{C}$ (data not shown).

Pathogenicity on sugar beet. Percent stand was high and ranged among isolates of $R$. solani AG-3 from 75 to $95 \%$ and from 76 to $90 \%$ in experiments 1 and 2, respectively (Table 1). Stand differed significantly $(P=0.05)$ among isolates of AG-3 in experiment 1 only, with isolates 93-33-4, 93-22-8, 93-22-13, 93-22-11, and 93-35-1 having lower stands than 93-34- 
6A or 93-33-9. Stands did not differ from the controls. Percent stand was not significantly different among isolates of $R$. solani AG-5 in the first experiment compared with the AG-5 tester isolate or the controls (Table 1). In the second experiment, percent stand was significantly $(P=0.05)$ different among isolates of $R$. solani AG-5. Isolates 93-28-5, 98-28-2, 93-28-1, and the AG-5 tester reduced stands considerably compared with the controls. Isolates of $R$. solani that were reisolated from dying seedlings were confirmed as the same AG used to infest the soil.

Root rot index values ( 0 to 7 scale) on older sugar beet roots inoculated with $R$. solani AG-3 or AG-5 were $\leq 1.0$ in both trials (data not shown), indicating that

Table 1. Percent stand of sugar beet planted in soil infested with hymenial isolates of Rhizoctonia solani AG-3 and AG-5

\begin{tabular}{|c|c|c|}
\hline \multirow[b]{2}{*}{ Treatment } & \multicolumn{2}{|c|}{$\%$ Stand $^{\mathrm{z}}$} \\
\hline & Exp. 1 & Exp. 2 \\
\hline \multicolumn{3}{|l|}{ R. solani AG-3 } \\
\hline $93-34-6 \mathrm{~A}$ & $95 \mathrm{a}$ & $90 \mathrm{a}$ \\
\hline $93-33-9$ & $95 \mathrm{a}$ & $90 \mathrm{a}$ \\
\hline $93-33-3$ & $92 a b c$ & $85 \mathrm{ab}$ \\
\hline $93-22-2$ & $92 \mathrm{abc}$ & $83 a b c$ \\
\hline $93-22-5$ & $91 a b c$ & $85 \mathrm{ab}$ \\
\hline $93-33-10$ & $90 \mathrm{abc}$ & $86 \mathrm{ab}$ \\
\hline $93-33-8$ & $89 a b c$ & $78 \mathrm{abcd}$ \\
\hline $93-33-5$ & $89 a b c$ & $85 a b$ \\
\hline $93-35-8$ & $88 \mathrm{abc}$ & $83 a b c$ \\
\hline $93-34-6 b$ & $88 \mathrm{abc}$ & $85 \mathrm{ab}$ \\
\hline $93-34-4$ & $88 \mathrm{abc}$ & $77 \mathrm{abcd}$ \\
\hline $93-34-3$ & $87 a b c$ & $91 \mathrm{a}$ \\
\hline $93-33-12$ & $87 \mathrm{abc}$ & $87 \mathrm{ab}$ \\
\hline $93-33-2$ & 85 abcd & $77 \mathrm{abcd}$ \\
\hline $93-33-6$ & 85 abcd & $83 a b c$ \\
\hline $93-22-6$ & 85 abcd & $85 \mathrm{ab}$ \\
\hline $93-22-10$ & 85 abcd & $79 a b c$ \\
\hline $93-35-3$ & $84 \mathrm{abcd}$ & $80 a b c$ \\
\hline $93-34-1$ & $83 \mathrm{abcd}$ & $85 \mathrm{ab}$ \\
\hline $93-34-2$ & $83 \mathrm{abcd}$ & $90 \mathrm{a}$ \\
\hline $93-22-2 d$ & $82 \mathrm{abcd}$ & $83 a b$ \\
\hline $93-22-1$ & 81 abcd & $76 \mathrm{abcd}$ \\
\hline $93-33-4$ & $81 \mathrm{bcd}$ & $85 \mathrm{ab}$ \\
\hline $93-22-8$ & $79 \mathrm{~cd}$ & $87 \mathrm{ab}$ \\
\hline $93-22-13$ & $79 \mathrm{~cd}$ & $80 a b c$ \\
\hline $93-22-11$ & $79 \mathrm{~cd}$ & $87 \mathrm{ab}$ \\
\hline $93-35-1$ & $75 \mathrm{~d}$ & $81 a b c$ \\
\hline Tester & $92 \mathrm{abc}$ & $87 \mathrm{ab}$ \\
\hline$\overline{\mathrm{X}}$ & 86 & 84 \\
\hline \multicolumn{3}{|l|}{ R. solani AG-5 } \\
\hline $93-28-4$ & $87 \mathrm{abc}$ & $64 \mathrm{de}$ \\
\hline $93-28-5$ & $83 \mathrm{abcd}$ & $49 \mathrm{f}$ \\
\hline $93-28-3$ & $83 \mathrm{abcd}$ & $69 \mathrm{cde}$ \\
\hline $93-28-2$ & 81 abcd & 58 ef \\
\hline $93-28-1$ & $80 \mathrm{~cd}$ & 57 ef \\
\hline Tester & $79 \mathrm{~cd}$ & 65 ef \\
\hline$\overline{\mathrm{x}}$ & 82 & 60 \\
\hline Control-WA & 86 abcd & $73 \mathrm{bcd}$ \\
\hline Control-Soil & 85 abcd & $79 \mathrm{abcd}$ \\
\hline
\end{tabular}

${ }^{\mathrm{z}}$ Each value based on 25 seeds planted in soil infested with $R$. solani on water agar (WA) for 3 weeks, six replicates. For each column, values followed by the same letter are not significantly different, $P=0.05$, Fisher's protected least significant difference (LSD). Values provided are nontransformed but mean separations are based on transformed data. these isolates were nonpathogenic. Root rot index values of the uninoculated controls were 0 and 0.2 for experiments 1 and 2 , respectively. Each isolate of AG-3, including the tester isolate, formed sclerotia $\leq 1 \mathrm{~mm}$ diameter on the sugar beet root surface (Fig. 2A). Across all isolates of AG-3, sclerotia formed on 90 and $98 \%$ of inoculated roots in experiments 1 and 2 , respectively. These sclerotia were confirmed as AG-3. Isolates of $R$. solani AG-5 did not form sclerotia on sugar beet roots in either experiment. Sclerotia did not occur on roots of control plants.

Pathogenicity on potato. There were no statistical $(P=0.05)$ differences in disease indices on potato sprouts held at $10^{\circ} \mathrm{C}$ for 6 weeks among isolates of $R$. solani AG-3, AG-5, or uninfested controls in either experiment (data not shown). Disease indices were low, and for experiments 1 and 2, respectively, they averaged 0.7 and 1.1 for AG-3, 0 and 1.0 for AG-5, and 0 and 1.0 for the uninfested control. All isolates of $R$.

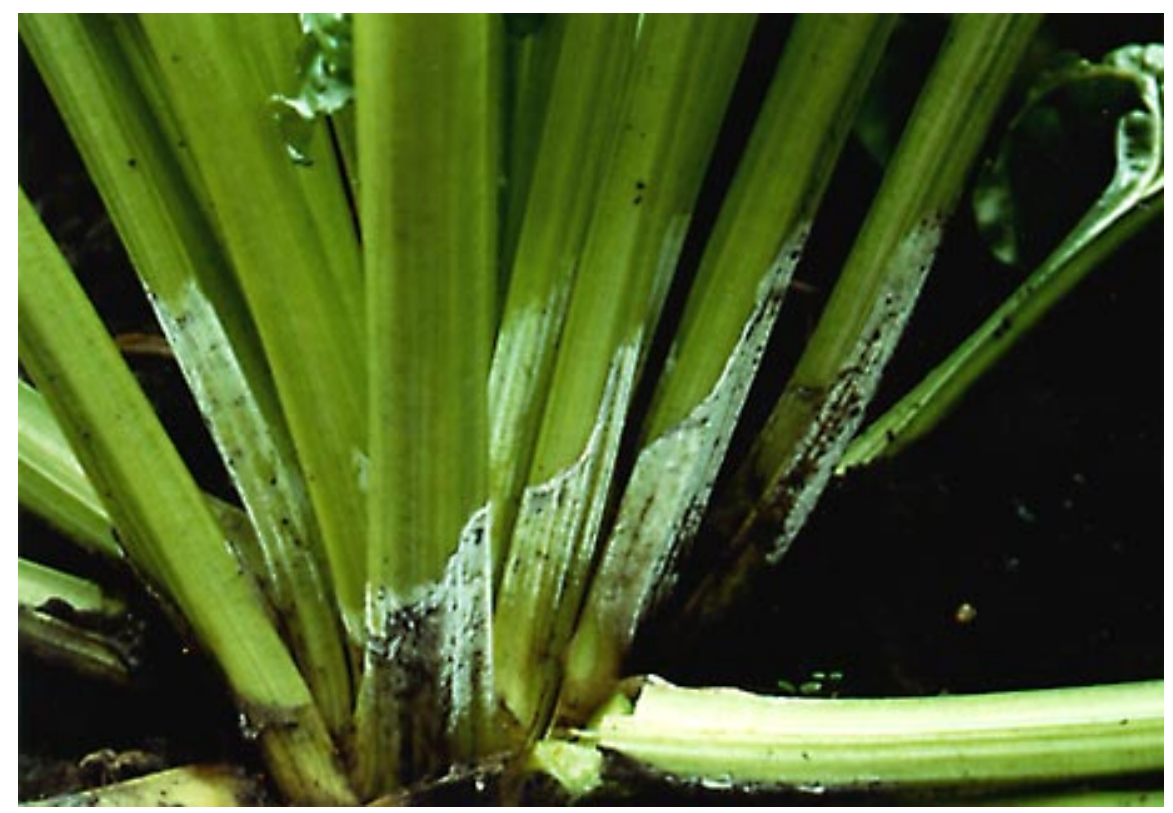

Fig. 1. Hymenial layer of Thanatephorus cucumeris on petioles of a sugar beet plant.

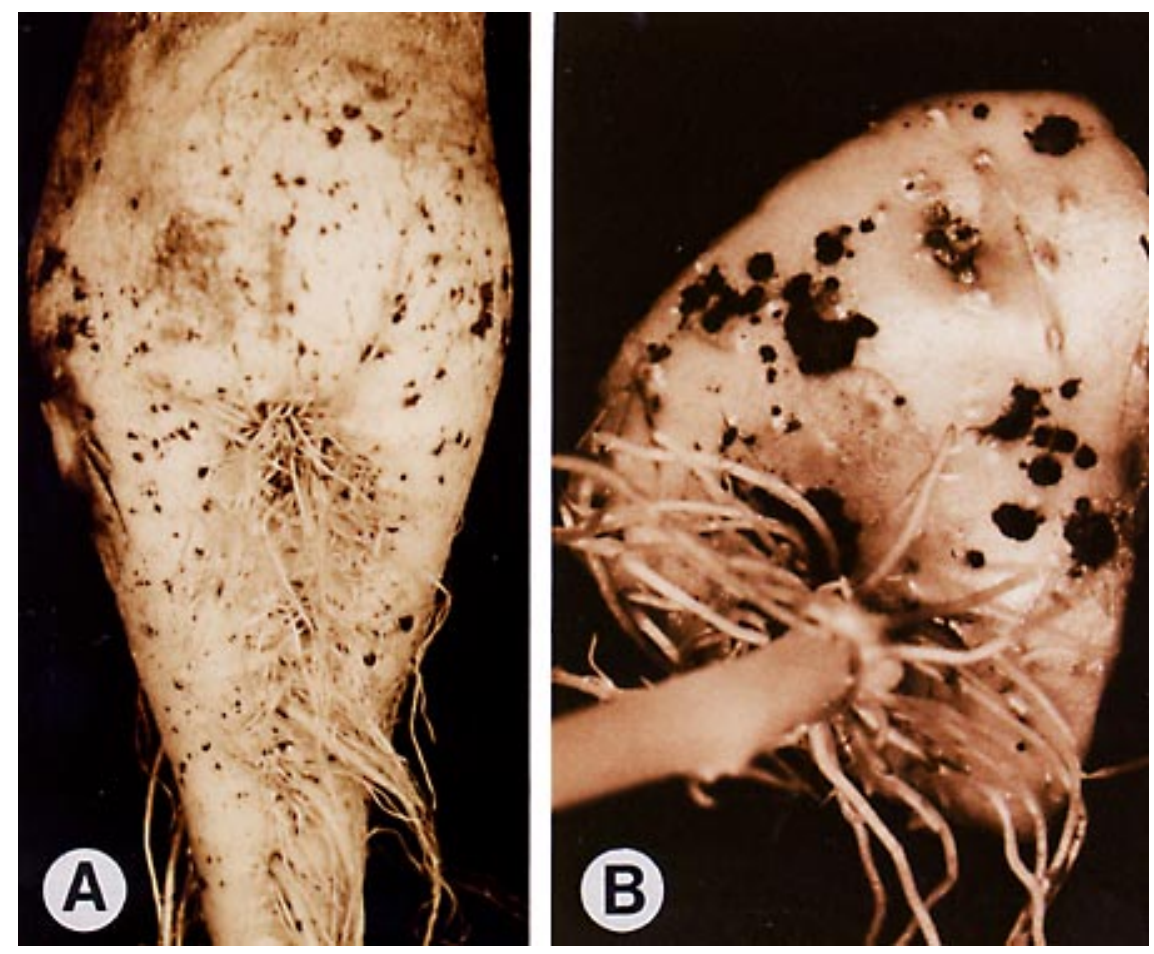

Fig. 2. Sclerotia of Rhizoctonia solani AG-3 on (A) sugar beet roots and (B) potato seed pieces. 
solani AG-3 formed sclerotia 1 to $3 \mathrm{~mm}$ in diameter on potato seed pieces (Fig. 2B). Across the 14 isolates of AG-3 evaluated, sclerotia formed on 61 and $43 \%$ of seed pieces in experiments 1 and 2, respectively (data not shown). Cultures isolated from these sclerotia were confirmed as AG-3. Soil inoculated with the three isolates of $R$. solani AG-5 did not result in formation of sclerotia on seed pieces. Sclerotia of AG-3 formed on one control seed piece in the second experiment. The seed piece may have been colonized by mycelium of $R$. solani before planting (11).

When potato sprouts were incubated at $25^{\circ} \mathrm{C}$ and evaluated 2 weeks after planting, there were significant $(P=0.0001$ and $P=$ 0.006 for experiments 1 and 2 , respectively) differences in disease indices among isolates of AG-3 and AG-5 compared with the uninfested control (data not shown). In experiment 1 , three isolates of $R$. solani AG-3 (93-35-1, 93-35-8, and 9322-10) resulted in disease indices of 0.8 , 0.4 , and 0.4 , respectively, and three isolates of AG-5 (93-28-3, 93-28-5, and 93-28-1) resulted in disease indices of $1.4,1.0$, and 0.8 , respectively, compared with a disease index of 0 in the control. In experiment 2 , an isolate of $R$. solani AG-3 (93-35-3) and one of AG-5 (93-28-5) resulted in disease indices of 1.0 and 2.0, respectively, and these values were significantly different (LSD, $P=0.05$ ) from the disease index of 0 in the control. Sclerotia did not form on seed pieces in soil infested with isolates of $R$. solani AG-3 or AG-5 or in the control.

\section{DISCUSSION}

This is the first report of T. cucumeris on petioles of sugar beet in the field where the anamorph is $R$. solani AG-3 or AG-5. In the samples observed, hymenia of $T$. cucumeris were limited to the petioles of sugar beet and were not associated with disease. In previous reports, the occurrence of T. cucumeris on beet petioles was associated with foliar blight or with root and crown rot caused by $R$. solani AG-1, -2 , or $-4(9,15)$.

Potato producers in this geographic region sometimes discard potato culls in lower portions of fields to "build up" the low areas. Hymenia of T. cucumeris $(=R$. solani AG-3) on sugar beet occurred only in lower portions of fields where potatoes had been planted the previous season and where potato culls and pieces occurred on the soil surface. These observations suggest that potato debris, i.e., discarded potato culls or soilborne root residue of the previous crop, served as a source of inoculum of AG-3 for infection of the subsequent sugar beet crop. Although $R$. solani AG-3 is reported to sporulate as T. сисиmeris on potato stems $(1,7)$, it is unknown if infection of sugar beet plants occurred from basidiospores or mycelium.

In the field where sugar beet petioles bearing hymenia of $T$. cucumeris yielded cultures of $R$. solani AG-5, there was no history of potato culture. However, AG-5 is reported on other crops grown in the region, including sugar beet (28), soybean (18), and wheat (24; C. E. Windels, unpublished).

Formation of the teleomorph in the field requires high relative humidity and optimal temperatures of 20 to $30^{\circ} \mathrm{C}(26)$. The 1993 field season was characterized by moderate temperatures and cloudy conditions, which may have produced a microclimate in the sugar beet canopy that favored development of T. cucumeris. Weather data from the Northwest Experiment Station, University of Minnesota, Crookston, recorded maximum temperatures between 20 and $30^{\circ} \mathrm{C}$ for 17 days in June and 27 days each in July and August 1993. Partly cloudy to cloudy weather occurred on 20 days in June and 23 days each in July and August. Also, hymenia of T. cucumeris on beets occurred in lower, wetter portions of fields and not on ridges, where soil was drier.

We reported previously that sugar beet yields were lower from plants with $T$. $\mathrm{cu}$ cumeris compared with healthy plants in the same field (27). This reduction in sugar beet yield could have resulted from high soil moisture in the lower areas of the field where hymenia of $T$. cucumeris occurred. On the other hand, the presence of hymenia of $T$. cucumeris on petioles of sugar beet could interfere with the production and translocation of nutrients to the root and thereby reduce yield.

Isolates of $R$. solani AG-3 and AG-5 cultured from petioles of sugar beet plants bearing hymenia of $T$. cucumeris were nonpathogenic to mildly pathogenic on sugar beet seedlings and nonpathogenic on older roots. These results concur with previous reports $(18,28)$. However, the presence of sclerotia of $R$. solani AG-3 on sugar beet roots in greenhouse experiments suggests that the fungus can increase its population on a nonhost species. Kohn (12) concluded that asexual reproduction by the sclerotial-forming plant pathogen Sclerotinia sclerotiorum resulted in clonal colonization and spread in the field. Whether formation of sclerotia of $R$. solani on sugar beet roots has practical significance in increasing inoculum or spread of clones of AG-3 remains uncertain, since sclerotia of this fungus were not observed on beet roots in the field.

Cultures of $R$. solani AG-3 and AG-5 isolated from $T$. cucumeris-infected beets caused minor damage on potato sprouts at 10 and $25^{\circ} \mathrm{C}$. These temperatures were selected for pathogenicity tests because $R$. solani AG-3 is reported to be most pathogenic on potato sprouts at $10^{\circ} \mathrm{C}(5) ; R$. solani AG-5 is pathogenic at $24 \pm 2{ }^{\circ} \mathrm{C}$ (3); and isolates of AG-3 and -5 in these studies usually grew most rapidly at $25^{\circ} \mathrm{C}$. Disease ratings might have been higher if a different cultivar had been used. Norland has some resistance to Rhizoctonia (11) but was selected for evaluations because it is a popular cultivar in the Red River Valley of Minnesota and North Dakota and because the certified seed was free from sclerotia of $R$. solani. The low disease rating on potato in our experiments differs from previous reports where isolates of $R$. solani AG-3 from hymenia were among the most pathogenic to potato compared with isolates of AG-3 from other sources $(4,11)$.

In summary, occurrence of hymenia of $T$. cucumeris on sugar beet was not an indicator of disease on these plants. In this study, $R$. solani AG-3 and AG-5 obtained from hymenia of $T$. cucumeris on sugar beet petioles were nonpathogenic or only mildly pathogenic to sugar beet and potato. The presence of hymenia on sugar beet in the field is significant in that genetic recombination and inoculum production of $R$. solani occurred on a nonhost crop. Infection of sugar beet by $T$. cucumeris was related to AGs of $R$. solani associated with the previous crop (AG-3 for potato and AG-5 for wheat), which suggests that rotation of nonhost crops contributes to the epidemiology of this fungus.

\section{ACKNOWLEDGMENTS}

This work was supported in part by a grant from the Sugar Beet Research and Education Board of Minnesota and North Dakota, Fargo, North Dakota 58105.

\section{LITERATURE CITED}

1. Adams, G. C. 1988. Thanatephorus cucumeris (Rhizoctonia solani), a species complex of wide host range. Pages 535-552 in: Advances in Plant Pathology. Genetics of Plant Pathogenic Fungi. Vol. 6. G. S. Sidhu, ed. Academic Press, New York.

2. Anderson, N. A. 1982. The genetics and pathology of Rhizoctonia solani. Annu. Rev. Phytopathol. 20:329-347.

3. Bandy, B. P., Zanzinger, D. H., and Tavantzis, S. M. 1984. Isolation of anastomosis group 5 of Rhizoctonia solani from potato field soils in Maine. Phytopathology 74:1220-1224.

4. Carling, D. E., and Leiner, R. H. 1990. Virulence of isolates of Rhizoctonia solani AG-3 collected from potato plant organs and soil. Plant Dis. 74:901-903.

5. Carling, D. E., and Leiner, R. H. 1990. Effect of temperature on virulence of Rhizoctonia solani and other Rhizoctonia on potato. Phytopathology 80:930-934.

6. Engelkes, C. A., and Windels, C. E. 1994 Relationship of plant age, cultivar, and isolate of Rhizoctonia solani AG-2-2 to sugar beet root and crown rot. Plant Dis. 78:685-689.

7. Grisham, M. P., and Anderson, N. A. 1983. Pathogenicity and host specificity of Rhizoctonia solani isolated from carrots. Phytopathology 73:1564-1569.

8. Gudmestad, N. C., Stack, R. W., and Salas, B. 1989. Colonization of potato by Rhizoctonia solani as affected by crop rotation. Pages 247 252 in: The Effects of Crop Rotation on Potato Production in the Temperate Zone. J. Vos and C. D. vanLoon, eds. Kluwer Academic Publishers, Boston.

9. Herr, L. J. 1982. Characteristics of hymenial isolates of Thanatephorus cucumeris on sugar beets in Ohio. Plant Dis. 66:246-249.

10. Herr, L. J., and Roberts, D. L. 1980. Characterization of Rhizoctonia populations obtained from sugarbeet fields with differing soil textures. Phytopathology 70:476-480. 
11. Hill, C. B., and Anderson, N. A. 1989. An evaluation of potato disease caused by isolates of Rhizoctonia solani AG-3. Am. Potato J. 66:709-721.

12. Kohn, L. M. 1995. The clonal dynamic in wild and agricultural plant-pathogen populations. Can. J. Bot. 73(Suppl. 1):S1231S1240.

13. Kotila, J. E. 1947. Rhizoctonia foliage blight of sugar beets. J. Agric. Res. 74:289-314.

14. Kuznia, R. A., and Windels, C. E. 1994. Preservation of Pythium species and Rhizoctonia solani at -80 C. (Abstr.) Phytopathology 84:1149.

15. Naito, S. 1990. Ecological role of basidiospores of Thanatephorus cucumeris (Frank) Donk in the incidence of foliage blight of sugar beets in Japan. JARQ, Jpn. Agric. Res. Quart. 23:268-275.

16. Naito, S., and Sugimoto, T. 1978. Basidiospore infection and lesion development on sugar beet leaves by Thanatephorus cucumeris (Frank) Donk. (In Japanese, with English abstract.) Ann. Phytopathol. Soc. Jpn. 44:426-431.

17. Naito, S., and Sugimoto, T. 1980. Relation- ship between basidiospore dispersal of Thanatephorus cucumeris (Frank) Donk and development of foliage blight of sugar beets. (In Japanese, with English abstract.) Ann. Phytopathol. Soc. Jpn. 46:216-233.

18. Nelson, B., Helms, T., Christianson, T., and Kural, I. 1996. Characterization and pathogenicity of Rhizoctonia from soybean. Plant Dis. 80:74-80.

19. Ogoshi, A. 1976. Studies on the grouping of Rhizoctonia solani Kühn with hyphal anastomosis and on the perfect stages of groups. Bull. Nat. Inst. Agric. Sci. Sec. C. 30:1-63.

20. Ogoshi, A. 1987. Ecology and pathogenicity of anastomosis and intraspecific groups of Rhizoctonia solani Kühn. Annu. Rev. Phytopathol. 25:125-143.

21. Olaya, G., and Abawi, G. S. 1994. Characteristics of Rhizoctonia solani and binucleate Rhizoctonia species causing foliar blight and root rot on table beets in New York State. Plant Dis. 78:800-804.

22. Parmeter, J. R., Jr., Sherwood, R. T., and Platt, W. D. 1969. Anastomosis grouping among isolates of Thanatephorus cucumeris. Phytopathology 59:1270-1278.
23. Ruppel, E. G., Schneider, C. L., Hecker, R. J., and Hogaboam, G. J. 1979. Creating epiphytotics of Rhizoctonia root rot and evaluating for resistance to Rhizoctonia solani in sugarbeet field plots. Plant Dis. Rep. 63:518-522.

24. Rush, C. M., Carling, D. E., Harveson, R. M. and Mathieson, J. T. 1994. Prevalence and pathogenicity of anastomosis groups of $R h i$ zoctonia solani from wheat and sugar beet in Texas. Plant Dis. 78:349-352.

25. Schmitthenner, A. F., and Hilty, J. W. 1962. A method for studying postemergence seedling root rot. Phytopathology 52:177-179.

26. Sneh, B., Burpee, L., and Ogoshi, A. 1991. Identification of Rhizoctonia Species. American Phytopathological Society, St. Paul, MN.

27. Windels, C. E., Kuznia, R. A., and Call, J. 1994. First report of Thanatephorus cucumeris (=Rhizoctonia solani AG-3 and AG-5) on sugar beet. (Abstr.). Phytopathology $84: 1161$.

28. Windels, C. E., and Nabben, D. J. 1989. Characterization and pathogenicity of anastomosis groups of Rhizoctonia solani isolated from Beta vulgaris. Phytopathology 79:83-88. 